\title{
Families Headed by Lesbian, Gay and Bisexual Individuals: A Systematic Literature Review
}

\author{
Aline Nogueira de Lira ${ }^{1}$ \\ Normanda Araujo de Morais \\ Programa de Pós-Graduação em Psicologia da Universidade de Fortaleza, \\ Fortaleza, CE, Brazil
}

\begin{abstract}
The aim of the present study was to describe the scientific literature on families constituted by lesbian, gay and bisexual individuals, through a systematic review of national and international studies published between 2009 and 2013. The following databases were searched: Scientific Electronic Library Online (SciELO), Periódicos Eletrônicos de Psicologia (PePSIC), Literatura Latino-Americana e do Caribe em Ciências da Saúde (LILACS), Index Psi, PsyINFO and PUBMED. After the application of inclusion and exclusion criteria, 145 articles were selected for review. Most studies were international, empirical, cross-sectional and quantitative, with a focus on lesbian parenthood. Content analysis of the articles revealed two major categories with a series of subcategories each: (a) Parenting (expectations, perceptions and transition to parenting; routes to parenthood; family dynamics and functioning; homophobia; and theoretical and methodological issues in the study of parenting in sexual minorities); (b) Marriage (marriage legalization; marital dynamics; support network; and homophobia). This review provides an updated and extensive discussion of the research into families headed by sexual minorities. Major findings are summarized and critically evaluated, and suggestions for future research are described.
\end{abstract}

Keywords: Family, parenting, marriage, homosexuality, same sex.

\section{Famílias Constituídas por Lésbicas, Gays e Bissexuais: Revisão Sistemática de Literatura}

\section{Resumo}

Buscou-se caracterizar a produção científica acerca das famílias constituídas por lésbicas, gays e bissexuais, a partir de uma revisão sistemática da literatura nacional e internacional, entre o período de 2009 a 2013. A busca foi feita nas bases Scientific Electronic Library Online (SciELO), Periódicos Eletrônicos de Psicologia (PePSIC), Literatura Latino-Americana e do Caribe em Ciências da Saúde (LILACS), Index Psi, PsycINFO e PUBMED, sendo identificados e analisados 145 artigos após a consideração dos critérios de inclusão e exclusão. Prevaleceram os estudos internacionais, empíricos, transversais, quantitativos e com ênfase na parentalidade lésbica. A análise de conteúdo dos artigos gerou a elaboração de duas categorias e suas sub-categorias, quais sejam: (a) Parentalidade (expectativas, percepções e transição para a parentalidade; estratégias de acesso à parentalidade; dinâmica e funcionamentos das relações pais/mães e filhos; homofobia e; discussões teóricas e metodológicas sobre a parentalidade); e (b) Conjugalidade (legalização do casamento; dinâmica conjugal; rede de

1 Mailing address: Rua Maria Teixeira Joca, 526, Casa 6, Centro, Eusébio, CE, Brazil 61760-000. Phone: (85) 8726-2118. E-mail: aline.lira09@hotmail.com 
apoio; e homofobia). Esta revisão ofereceu um panorama atual e abrangente dos estudos, sintetizando-o, lançando um olhar crítico a esse cenário multifaceado, além de indicar possibilidades para futuras investigações.

Palavras-chave: Família, parentalidade, conjugalidade, homossexualidade, mesmo sexo.

\section{Familias Compuestas por Lesbianas, Gays y Bisexuales: Revisión Sistemática de Literatura}

\section{Resumen}

Se ha buscado caracterizar la producción científica acerca de las familias compuestas por lesbianas, gays y bisexuales a partir de una revisión sistemática de la literatura nacional e internacional, en el período 2009-2013. La búsqueda se realizó en las bases Scientific Electronic Library Online (SciELO), Periódicos Eletrônicos de Psicologia (PePSIC), Literatura Latino-Americana e do Caribe em Ciências da Saúde (LILACS), Index Psi, PsycINFO y PUBMED. Se identificaron y se analizaron 145 artículos tras el examen de los criterios de inclusión y exclusión. Se han prevalecido los estudios internacionales, empíricos, transversales, cuantitativos y con énfasis en la parentalidad lesbiana. El análisis de contenido de los artículos ha generado dos categorías y sus subcategorías, a ver: (a) Parentalidad (expectativas, percepciones y transición para la parentalidad; estrategias de acceso a la parentalidad; dinámica y operación de las relaciones padres/madres e hijos; homofobia y; discusiones teóricas y metodológicas sobre la parentalidade); e (b) Conyugalidad (legalización del matrimonio; la dinámica de la pareja; redes de apoyo; y homofobia). Esta revisión ofreció un panorama largo y actual de los estudios, de forma a sintetizarlos con una visión crítica acerca del escenario múltiple, para allá de indicar posibilidades para futuras investigaciones.

Palabras clave: Familia, parentalidad, conyugalidad, homosexualidad, mismo sexo.

The scientific study of families headed by lesbian, gay and bisexual (LGB) ${ }^{2}$ individuals has flourished in recent years. This area of research became especially prominent in the 1970 s, although at that time, most studies focused on the mental health of lesbian mothers and the potential negative effect of parental homosexuality on offspring psychosexual development (Johnson, 2012). In recent decades, however, studies have made great progress in the understanding of LGB family processes and dynamics, especially among lesbian women, evaluating both the difficulties faced by these families, but also the

\footnotetext{
We use the term LGB to refer specifically to studies involving lesbian, gay and bisexual, but not trans (transvestite, transsexual), participants. The term LGBT will be used to describe the "LGBT community" or to refer to studies which included all LGBT populations.
}

positive aspects of these family configurations (Goldberg \& Gartrell, 2014).

LGB families still experience discrimination in several contexts, including the health, welfare, education and legal systems (Power et al., 2010). However, a sizeable body of scientific evidence gathered over the past 40 years attests to the well-being of children in same-sex parented families, suggesting that psychosocial developmental is not impaired by parental sexual orientation (Goldberg \& Gartrell, 2014). According to the latest reviews of the literature on same-sex parenting - which mostly focus on lesbian, gay, and bisexual families -, poverty, parental depression, divorce, parental substance abuse, and domestic violence are risk-factors for poor psychosocial functioning in both childhood and adulthood, while parental sexual orientation has no negative effects on child development (Biblarz \& Stacey, 2010; Cecílio, 
Scorsolini-Comin, \& Santos, 2013; Goldberg \& Gartrell, 2014).

Empirical studies of same-sex couples demonstrate that these individuals face similar issues to those reported by heterosexual couples (Henderson, Lehavot, \& Simoni, 2009). Same-sex relationships are characterized by deep emotional bonds and commitment, and may experience several issues of intimacy, love, faithfulness, and relationship stability. Nevertheless, these couples continue to be stigmatized as a result of their sexual minority status (Frost \& Meyer, 2009; Lomando, Wagner, \& Gonçalves, 2011). The experience of prejudice events, the need to hide or conceal one's sexual orientation, and internalized homophobia are significant sources of stress for sexual minorities (Meyer, 2003), and often have a negative effect on same-sex couples, decreasing marital satisfaction, intimacy, and individual well-being and mental health (Henderson et al., 2009).

Despite the growing number of studies into "families and homosexuality," and the increase in social and legal debates on the topic, misconceptions regarding LGB families continue to permeate the social milieu. The fear that parental sexual orientation could have a negative effect on psychosocial development, that the children of LGB parents are more likely to identify as gay/lesbian, or even the assumption of associations between homosexuality and promiscuity, continue to feed homophobic attitudes in society (Farias, 2010). In light of these observations and the discrimination faced by these individuals, the psychological literature should invest more resources into the study of families headed by LGB individuals, discussing these situations and shedding light on the specific issues faced by these families.

The aim of the present study was therefore to describe the scientific literature on families constituted by lesbians, gays and bisexuals, through a systematic review of national and international studies published between 2009 and 2013. A general picture of the scientific literature on the topic was provided, highlighting both the advances and weaknesses in the literature, as well as significant areas for future research.
Additionally, a comprehensive characterization of the literature on both parental and marital issues was performed, since childless couples are themselves a type of family arrangement. The geographic range of this review was also significantly larger than that of other similar studies in the literature, most of which are limited to North-American and European studies. The present review also included articles published in Latin America and Brazil, so as to construct a systematic and comprehensive compilation of current knowledge on the topic.

\section{Method}

This systematic review aimed to describe the scientific literature on families headed by LGB individuals.

\section{Procedures}

The literature review was performed in eight stages (Costa \& Zolowski, 2014):

1. Definition of a main research question;

2. Database selection;

3. Selection of keywords for the literature search;

4. Database search and retrieval of results;

5. Abstract screening based on inclusion and exclusion criteria;

6. Extraction of data from selected articles;

7. Article evaluation;

8. Data synthesis and interpretation.

\section{Data Collection}

The following databases were searched: Scientific Electronic Library Online (SciELO), Periódicos Eletrônicos de Psicologia (PePSIC), Literatura Latino-Americana e do Caribe em Ciências da Saúde (LILACS), Index Psi, PsycINFO and PUBMED. The following keywords and Boolean operators were used to retrieve articles in Portuguese: "(homossexual OR lésbica OR gay OR homoparental OR lgbt) AND (familias OR parentalidade OR conjugalidade OR casamento OR maternidade OR paternidade)". To search the Englishlanguage literature, the following keywords were used: "(homosexual OR lesbian OR gay OR lgbt 
OR same-sex) AND (families OR parenting OR parenthood OR mother OR father)". To retrieve articles in French, the following keyword was used: "homoparentalité". The literature search was performed in June and July 2014. The databases were searched for articles published between 2009 and 2013, so as to identify publications which captured recent changes in legal, juridical, social and academic contexts with regards to family and homosexuality, as well as the increase in the number of publications on the topic observed over the past few years. The selection of this particular time period was also based on previous reviews of the literature on family and homosexuality, which have offered a comprehensive perspective of the literature on the topic, especially in the context of LGB parenting (e.g. Biblarz \& Stacey, 2010; Cecílio et al., 2013; Vecho \& Schneider, 2005). This period was considered sufficiently long to identify the major trends and findings in this area of research.

The following inclusion criteria were applied to the abstracts: indexed articles published in Portuguese, English, Spanish and French; theoretical and empirical studies; full-text availability; publication between 2009 and 2013; involvement of human subjects. All abstracts retrieved were then analyzed, considering the following exclusion criteria: duplicates; book chapters; news items; technical documents; commentaries; literature reviews (systematic and narrative); dissertations and theses; publications outside the specified time period; and studies which focused on homosexuality, but not family.

Systematic literature reviews were not included in the analysis since the goal of this study was to describe the scientific literature on LGB families with regards to its goals, methods, themes and results. However, the reviews were used to situate our findings in the context of the existing literature (e.g. Biblarz \& Stacey, 2010; Cecílio et al., 2013; Goldberg \& Gartrell, 2014; Santos, Scorsolini-Comin, \& Santos, 2013).

After a preliminary screening of the abstracts according to inclusion and exclusion criteria, the full-text articles were obtained for closer inspec- tion and analyzed by two independent judges - one undergraduate and one graduate student, both members of the research group on same-sex families headed by the first author of this study. A relevance test was then performed (Azevedo, 2010). All excluded articles were discussed by the judges, and disagreements were resolved by consensus. The final set of selected studies was then read in full, and data were extracted and entered into Excel spreadsheets.

\section{Data Analysis}

Data synthesis and interpretation involved two types of analysis. A quantitative method was first used to describe the profile of the studies retrieved, in terms of their year of publication, nationality of the institutions to which the first authors were affiliated, journals of publication, language, type of study, method, study design, instruments, participant characteristics, and family arrangements studied. The second method was qualitative, and involved a synthesis of the themes discussed in the articles (Bardin, 1977/1979), and the a posteriori mapping of two comprehensive categories for analysis - parenting and marriage - as well as corresponding subcategories. The (sub) categories were identified by the following method: (a) pre-analysis - themes were identified based on a first reading of the articles reviewed, during which hypotheses and objectives were developed, and indicators for further analysis were identified; (b) exploration of the material - data were explored and information items were coded; (c) compilation and interpretation of results -information items were classified according to their similarities and differences, to reveal the major themes of the articles analyzed. After the identification of the main thematic categories, data were presented and discussed in the context of the existing literature in this area of study.

\section{Results and Discussion}

The initial search retrieved a total of 4,869 studies (PUBMED: 4,589; PsycINFO: 159; SciELO: 42; PePSIC: 23; LILACS: 40; 
IndexPsi: 16). The abstracts were screened, and the application of inclusion and exclusion criteria resulted in the exclusion of articles for the following reasons: articles in duplicate $(n$ $=48$ ); publication dates outside the specified time period $(n=3,698)$; non-human samples $(n=101)$; abstract unavailability $(n=77)$; gray literature $(n=87)$; studies which did not focus on "family and homosexuality" $(n=563)$.

A total of 295 studies were selected for inclusion, but only 289 were obtained in full text format, even after direct contact with the authors and the use of bibliographic retrieval systems. Nevertheless, the number of articles retrieved represents the vast majority of abstracts selected $(97.96 \%)$

These articles were then sent to the judges for relevance testing (Azevedo, 2010). The main reasons for article exclusion at this stage of the process were: not including "family" as a main topic of study, and focusing instead on other aspects of the LGBT identity (for instance, suicide among homosexual youth); investigating marital relationships in childless couples only; unclear objectives and implications. As such, the final sample consisted of 145 studies retrieved from the following databases: PUBMED ( $n$ $=109)$; PsycINFO $(n=17)$; SciELO $(n=10)$; PePSIC $(n=7)$; LILACS $(n=1)$ and IndexPsi $(n$ $=1)$. Articles included in the review are indicated with an asterisk in the Reference section $\left(^{*}\right)$.

\section{Quantitative Analysis of Scientific Studies}

Table 1 presents the characteristics of the articles analyzed. Most studies were written in English $(n=125)$, followed by Portuguese (16 articles). The majority of first authors were affiliated with institutions in the United States ( $n=$ 77), Brazil $(n=15)$ and the United Kingdom ( $n=$ 11). Thirty-one articles were published in 2013, while 31 were published in 2012, 28 in 2011, 30 in 2010 and 25 in 2009.

A total of 122 articles were empirical, while 23 were theoretical. Most empirical studies were cross-sectional $(n=110)$, although some were longitudinal $(n=12)$. Seven of the studies performed in Brazil were theoretical, while eight were empirical (and cross-sectional). These findings suggest an increase in the volume of empirical research over recent years. Most studies were quantitative $(n=62)$, although some used qualitative methods $(n=53)$. Mixed methods were only used by seven of the articles retrieved. Most quantitative studies relied on the use of scales, standardized questionnaires, and self-administered interviews. In most cases, data were analyzed using chi-square tests, multivariate and regression analysis. Two studies developed and validated parenting scales such as the Scale Beliefs about Children's Adjustment on Same-sex Families - SBCASSF (Frias-Navarro \& Monterde-i-Bort, 2012). This finding underscores the need for instrument validation in the LGB population, since most of the instruments used in the studies reviewed were developed for heterosexual populations. Qualitative studies relied mostly on structured and semi-structured interviews. Data analysis generally involved a content analysis by theme.

The sample size of each study ranged from 1 to 6864 people. Most studies, especially those which investigated parenting, involved lesbian (single, married, divorced; $n=33$ ) or gay participants $(n=23)$. Although 'transgender' was not included as a keyword in our literature search, three studies which had "family and homosexuality" as a main theme included this population in their analysis (Chapman et al., 2012; Knoble \& Linville, 2012; Zanghellini, 2010). Nineteen studies involved the offspring of LGB parents, who ranged in age from childhood ( $n=$ $6)$, through adolescence and young adulthood ( $n$ $=11)$, adulthood $(n=1)$, and old age $(n=1)$. The number of studies which focus on the offspring of LGB parents has increased significantly, although such investigations are still quite limited, especially with regard to adult offspring. Some studies also involved heterosexual adults, including consumers, Christians, university students, health care workers and education personnel $(n=17)$.

The scientific literature on families headed by LGB individuals addresses two main themes: parenting $(n=92)$ and marriage $(n=53)$. The fact that most studies focus on parenting 
may be attributable to concerns regarding the effects of parental sexual orientation on offspring psychosocial adjustment (Biblarz \& Stacey, 2010; Santos et al., 2013). Most of the studies published in the past five years focus on family arrangements such as adoption and assisted reproduction. Two studies focused on coparenting (Tarnovski, 2011, 2013). These results reflect the many legal, juridical, and technological changes observed in recent years, all of which have had an impact on the definition and organization of the family unit.

\section{Table 1}

Quantitative Characteristics of Studies Retrieved $(n=145)$

\begin{tabular}{|c|c|c|}
\hline $\begin{array}{l}\text { Quantitative } \\
\text { Categories }\end{array}$ & $\begin{array}{l}\text { Sample } \\
\text { (Overall) }\end{array}$ & $\begin{array}{l}\text { Sample } \\
\text { (Brazil) }\end{array}$ \\
\hline Year & $\begin{array}{l}2013(n=31) \\
2012(n=31) \\
2011(n=28) \\
2010(n=30) \\
2009(n=25)\end{array}$ & $\begin{array}{l}2013(n=2) \\
2012(n=2) \\
2011(n=5) \\
2010(n=2) \\
2009(n=4)\end{array}$ \\
\hline & $\begin{array}{c}\operatorname{USA}(n=77) \\
\operatorname{Brazil}(n=15) \\
\operatorname{UK}(n=11)\end{array}$ & \\
\hline $\begin{array}{l}\text { Nationality/state } \\
\text { of origin of the } \\
\text { first author }\end{array}$ & $\begin{array}{c}\text { Australia }(n=10) \\
\text { Canada }(n=7) \\
\text { Portugal }(n=4) \\
\text { Netherlands, Spain } \\
\text { and Israel }(n=3 \text { per country }) \\
\text { Sweden, Norway and Belgium }(n=2) \\
\text { Denmark, China, Colombia, France, } \\
\text { Hungary and Taiwan }(n=1)\end{array}$ & $\begin{array}{c}\text { São Paulo }(n=5) \\
\text { Rio de Janeiro }(n=4) \\
\text { Mato Grosso and Recife }(n=2) \\
\text { Minas Gerais, Paraíba, Porto Alegre }(n=1)\end{array}$ \\
\hline Type of study & $\begin{array}{l}\text { Empirical }(n=122) \\
\text { Theoretical }(n=23)\end{array}$ & $\begin{array}{l}\text { Empirical }(n=8) \\
\text { Theoretical }(n=7)\end{array}$ \\
\hline Study design & $\begin{array}{l}\text { Cross-sectional }(n=110) \\
\text { Longitudinal }(n=12)\end{array}$ & $\begin{array}{l}\text { Cross-sectional }(n=9) \\
\text { Longitudinal }(n=0)\end{array}$ \\
\hline Data analysis & $\begin{array}{c}\text { Quantitative }(n=62) \\
\text { Qualitative }(n=53) \\
\text { Multimethod }(n=7)\end{array}$ & $\begin{array}{l}\text { Quantitative }(n=1) \\
\text { Qualitative }(n=8)\end{array}$ \\
\hline $\begin{array}{c}\text { Sample/ } \\
\text { Participants }\end{array}$ & $\begin{array}{c}\text { Gay }(n=23) \\
\text { Lesbian }(n=33) \\
\text { Children }(n=19) \\
\text { Gay and Lesbian }(n=22) \\
\text { Gay, lesbian, bisexual } \\
\text { and heterosexual }(n=11) \\
\text { Transgender }(n=3) \\
\text { Health professionals, educators, } \\
\text { university students }(n=17)\end{array}$ & $\begin{array}{c}\text { Gay }(n=3) \\
\text { Lesbian }(n=2) \\
\text { Children }(n=1) \\
\text { Gay and Lesbian }(n=2) \\
\text { Health professionals, educators, } \\
\text { university students }(n=1)\end{array}$ \\
\hline Materials & $\begin{array}{l}\text { Questionnaires and scales }(n=44) \\
\text { Interviews }(n=51)\end{array}$ & $\begin{array}{l}\text { Questionnaires and scales }(n=1) \\
\text { Interviews }(n=8)\end{array}$ \\
\hline Theme & $\begin{array}{l}\text { Parenting }(n=92) \\
\text { Marriage }(n=53)\end{array}$ & $\begin{array}{l}\text { Parenting }(n=12) \\
\text { Marriage }(n=3)\end{array}$ \\
\hline
\end{tabular}




\section{Qualitative Analysis of Scientific Studies}

The qualitative analysis of the articles reviewed involved the classification of each study based on its main theme - parenting or marriage in families headed by LGB individuals - as well as a discussion of its main findings. A critical analysis of the research was also performed, reviewing its strengths as well as its weaknesses, and suggesting directions for future work.

Parenting among Lesbians, Gays and Bisexuals. The theme of "parenting" contained the following subcategories: (a) expectations, perceptions and the transition to parenting ( $n=$ 13); (b) routes to parenthood $(n=23)$; (c) parent/child dynamics and functioning $(n=22)$; (d) discrimination experiences and the impact of homophobia on the life of LGB-parent families ( $n$ $=25$ ); (e) theoretical and methodological discussions regarding parenting $(n=9)$. Examples of each subcategory are shown in Table 2, together with the number of articles in which each theme was discussed.

Studies of the expectations, perceptions and the transition to parenting revealed that gay and lesbian couples were less likely than heterosexual couples to express the desire for parenthood, especially due to legal issues and concerns regarding their children's psychosocial development. However, they endorsed the value of parenthood as strongly as did heterosexual individuals, and felt equally capable of parenting (e.g. Goldberg \& Smith, 2009; Riskind \& Patterson, 2010). Overall, it appears that the main barriers to parenthood for gay and especially lesbian couples are: legal and juridical issues (Ryan, 2013), difficulty conceiving and lack of social support during the conception process (Yager, Brennan, Steele, Epstein, \& Ross, 2010), as well as concerns about parenting itself, especially with regards to the psychosocial development of their offspring (Riskind \& Patterson, 2010; Riskind, Patterson, $\&$ Nosek, 2013). Nevertheless, lesbian and gay individuals tend to be confident in their ability to overcome legal, economic and social barriers to parenthood, especially when adoption is offered as an alternative to biological parenting
(Riskind et al., 2013). Additionally, despite their awareness of the challenges associated with transracial adoption, lesbian individuals are more open to this alternative than heterosexual subjects (Goldberg, 2009).

Despite the importance of the transition to parenting in families headed by LGB individuals, very few studies have looked into this phenomenon. Overall, studies showed that gay and lesbian parents present experience similar issues to heterosexual couples during the transition to parenthood, such as: decreased mental health and marital quality after the onset of parenthood (Goldberg \& Smith, 2011); decreased sexual satisfaction due to reduced investment of time and effort into the marital relationship, as a result of greater dedication to the primary relationship (Goldberg \& Smith, 2009).

Despite these advances, research into the expectations, perceptions and transition to parenting, especially among gay males, still leaves many questions unanswered, such as: what are the parenthood expectations of single vs. married individuals? How do individuals experience the transition to parenting when one member of the couple has already had children? How is the transition to parenthood for sexual minorities shaped by financial and educational resources? How do these families obtain support to cope with the stress associated with this difficult transition? (Goldberg \& Gartrell, 2014).

As for the main routes to parenthood, most studies, especially those published in the late 1990s and early 2000s, discuss planned parenthood through assisted reproduction (donor insemination and surrogacy) and adoption. This represents a significant change in the familybuilding process for the LGB population, since earlier studies focused on the experience of parents whose offspring had been conceived in heterosexual relationships which preceded their current homosexual partnership, as highlighted by Biblarz and Stacey (2010).

Families formed by lesbian women through donor insemination have received increasing visibility in the literature in recent years, not least due to advances in the sophistication and 
access to reproductive technology, as well as recent legislative changes (e.g. Grover, Shmorgun, Moskovtsev, Baratz, \& Librach, 2013; Moás \& Correa, 2010). Many studies focus on ethical, legal and couple intimacy issues in the context of the decision to use (known or unknown) donor sperm, and the implications of this decision for the marital relationship and the child's psychosocial development (e.g. Bos \& Gartrell, 2010a). Unknown donors are usually selected out of a wish to avoid the involvement of a third-party in the life of the child and couple, and the fear of custody challenges (e.g. Goldberg \& Allen, 2013). Known donors, on the other hand, may be chosen by women who believe their children deserve access to their biological heritage, or who wish to ensure their offspring have at least one male role model (e.g. Goldberg \& Allen, 2013). The literature suggests that having access to information about a child's donor is important for some parents and has potentially positive consequences for children, as it enhances their sense of identity (e.g. Freeman, Jadva, Kramer, $\&$ Golombok, 2009). There has also been an increase in studies which investigate how adolescents and young adults raised by lesbian mothers make meaning out of and construct their relationship with known donors (e.g. Goldberg \& Allen, 2013).

Gay men, either single or married, often choose to form a family through surrogacy (e.g. Greenfeld \& Seli, 2011; Smith, Willmott, Trowse, \& White, 2013). Studies also reveal that the increasing legalization of same-sex marriage has coincided with an increase in the number of gay men seeking fertility treatments (e.g. Grover et al., 2013). However, the question of how children feel toward their surrogate mothers has not yet been answered by the literature.

It is important to note that studies of donor insemination (involving lesbian parents) and surrogacy (involving gay parents) deal almost exclusively with participants with a high socioeconomic status. There is, as such, a need for studies which consider the influence of financial aspects, race, class, and gender on the decisionmaking process of LGB-parent families, and for an increase in the representativeness of partici- pant samples, to ensure that the findings in the literature can be generalized across socioeconomic conditions.

Most of the adoption studies included in this review suggest that the emotional bonds between adoptive children and their parents, the psychosocial adjustment of early-adopted children, and the development of parenting skills during the transition to adopted parenting do not vary as a function of parental gender or sexual orientation (e.g. Goldberg \& Smith, 2013). The transition to adoptive parenthood in LGBheaded families is a gradual process, which, for some individuals, begins with the first interaction with the adopted child (Amazonas, Veríssimo, $\&$ Lourenço, 2013). Another important point revealed by the present study, which also corroborates previous research, is that adoptive LGB parents experience high levels of stress due to social, legal and family discrimination (e.g. Tornello, Farr, \& Patterson, 2011). However, research has made great strides in studying how homosexual parents respond to discrimination during the adoption process, and the strategies they use to overcome discrimination and adopt their children (Bos \& Gartrell, 2010b).

The recent literature on parent/child $d y$ namics and functioning continues to corroborate the findings of previous studies (Biblarz \& Stacey, 2010; Goldberg \& Gartrell, 2014), in that children of same-sex parents do not appear to show any impairments in their social, cognitive, or psychosocial development due to their parent's sexual orientation (e.g. Bos \& Gartrell, 2010a; Farr, Forssell, \& Patterson, 2010). Studies of psychosocial adjustment focused especially on the comparison to heterosexual families, and found that the factors associated with positive developmental trends in children raised by heterosexual parents are similarly important in families headed by same-sex parents: positive family relationships (closeness, effective parent-child communication, high levels of marital satisfaction); secure attachments; adequate parental skills; parental mental health (e.g., absence of parental depression); absence of domestic violence; absence of psychoactive substance abuse (e.g. Gartrell \& Bos, 2010). 
The recent increase in the number of longitudinal studies in this area of research represents an important methodological and theoretical achievement. In addition to evaluating developmental outcomes, longitudinal studies can shed light on the influence of several factors (social, cultural, legal, and family issues, as well as life events) on psychosocial adjustment, in addition to identifying both protective and risk factors for developmental pro-blems (e.g. Gartrell, Bos, Peyser, Deck, \& Rodas, 2012). Recent studies have also begun to evaluate the perception of offspring (children, adolescents and young adults) toward their fa-milies, which represents a significant departure from earlier paradigms, most of which focused exclusively on parental perceptions of their children (e.g. Gartrell, Bos, \& Goldberg, 2011).

Although the literature has not identified any relevant differences in the frequency with which the offspring of heterosexual and samesex couples identify as gay or lesbian (Tasker \& Golombok, 1997), studies performed by Schumm (2010) suggest a tendency toward the intergenerational transfer of sexual orientation, especially for lesbian mothers of female children. Longitudinal investigations performed by Gartrell et al. (2011) also found that the adolescent daughters of lesbian mothers are more likely to engage in same-sex sexual behavior and identify as bisexual. The literature does not explain, however, whether girls raised by lesbian mothers are more likely to form same-sex relationships due to the influence of parental sexual orientation, or due to differences in sexual socialization and a more diverse notion of sexual orientation (Cohen \& Kuvalanka, 2011).

Studies of the parenting performance of gay, lesbian and bisexual parents - including parental skills and the quality of parent-child relationships - suggest a high degree of similarity between LGB- and heterosexual-parent families, which indicates that sexual orientation is not related to parenting skills or capabilities (Farr \& Patterson, 2013). The few existing differences appear to favor same-sex couples - especially those composed of lesbian women whose division of domestic tasks and child care, decision-making involvement, and participation in family interaction is far more egalitarian than that observed in heterosexual couples (e.g. Farr $\&$ Patterson, 2013). However, it is important to note that the egalitarianism observed in most lesbian families should not be universally upheld or perpetuated. In fact, doing so may lead to inattention to inequity in same-sex partners and the mistaken assumption that differential contributions inevitably cause tension and distress (Goldberg \& Gartrell, 2014). Some couples may not fit the "egalitarian ideal" and take on distinct specialized roles depending on the ease with which they perform certain tasks, or the features of the family arrangement in which their children were conceived (e.g. Martinez \& Barbieri, 2011).

A considerable number of studies also found that discrimination experiences and the impact of homophobia on the life of same-sex families is an important issue for the offspring of sexual minorities (Bos \& Gartrell, 2010b; Rodriguez \& Paiva, 2009). Gay, lesbian, and transgender parents, together with their children, may also experience discrimination or differential treatment in health care services - during pre- and post-natal care, for instance -, when trying to obtain private health insurance for their children, and when interacting with social workers, education personnel and legal representatives (e.g. Chapman et al., 2012). Studies of sexual minority stress continue to indicate that both internal and external homophobia have a significant negative impact on the physical and mental health of the LGB population (Meyer, 2003), as well as the psychological well-being of the offspring of LGB parents (e.g. Bos \& Gartrell, 2010a), especially due to their constant contact with legal and social contexts which may not support their marital relationship and family arrangement. However, our findings suggested that the adverse effects of homophobia may be attenuated by a strong social support network formed by members of the nuclear family (close parent-child and/or marital bonds), the family of origin, work colleagues, friends, or even legal and institutional representatives (e.g. Bos \& Gartrell, 2010b; Lomando et al., 2011). 
Research also suggests that there is a consensus in the general public - including health care and education personnel, university students, Christians, and the general heterosexual population - that children raised by heterosexual families have a developmental advantage over those raised by gay and lesbian parents (e.g. Ferreira, Cadete, \& da Silva, 2012; Gato \& Fontaine, 2013). The present findings are consistent with those of previous studies (e.g. Herek, 2000) in that people tend to have a more negative attitude toward gay parents than lesbian ones, suggesting that patterns of discrimination vary according to the sex of the sexual minority in question (e.g. Costa et al., 2013).

Lastly, some articles include a comprehensive discussion of the theoretical and methodological issues associated with the study of LGBT-parent families. These studies provide theoretical reflections on new family arrangements and discuss the need to overcome crystallized heteronormative attitudes (e.g. Rodriguez \& Gomes, 2012; Vilhena, Souza, Uziel, Zamora, \& Novaes, 2011). Some studies also validated parenting scales (e.g. FriasNavarro \& Monterde-i-Bort, 2012) and described the theoretical and methodological basis for longitudinal studies (e.g. Power et al., 2010).

Marriage in Lesbian, Gay and Bisexual Populations. Four main themes were identified in the literature on same-sex couples published between 2009 and 2013: (a) marriage legalization ( $n=17)$; (b) marital relationship dynamics $(n=19)$; (c) support network $(n=10)$ and; (d) homophobia and its impact on marital life $(n=$ 9). Table 2 shows examples of the references cited in each of these subcategories.

Studies which address the legalization of marriage between same-sex couples focus mostly on justifying or contesting the idea that the legal status of same-sex relationships could weaken the family institution, and that the children conceived in these unions would experience negative effects on their psychosocial development (e.g. Knauer, 2012). Scientific evidence, however, suggests that the legalization of same-sex unions has a positive effect on physical and psychosocial well-being, decreasing the mental health burden of lesbian, gay, bisexual and heterosexual populations, and providing tangible benefits to the daily lives of these individuals (Wight, LeBlanc, \& Lee Badgett, 2013), which may have a positive effect on parenthood. The legalization of same-sex marriage led to a decrease in the use of health care and mental health care services among gay and lesbian populations (Hatzenbuehler et al., 2012), a reduction in mortality rates for these individuals - though these rates are still higher than those observed in the general population - (Frisch \& Brønnum-Hansen, 2009), and a decrease in the psychological stress levels shown by lesbian and gay individuals (internalized homophobia, depressive symptoms and stress), maximizing their psychological well-being (e.g. Riggle, Rostosky, \& Horne, 2010). The articles reviewed highlight potential positive effects of marriage legalization including tangible economic benefits, a sense of greater relational stability due to the legal status of the relationship, positive effects on intimacy and closeness, as well as increased emotional support and selfesteem (e.g. Wight et al., 2013). Nevertheless, future research should still investigate the association between marriage legalization and the psychosocial adjustment of same-sex couples (illegal substance use, subjective well-being, life satisfaction, etc.). The impact of legalization on the physical and psychological health of the offspring of same-sex couples also deserves further investigation. Ideally, these issues should be addressed by longitudinal studies.

As for the relational dynamics of same-sex couples, studies suggest that changes to the legal status of same-sex unions may influence the way younger generations of same-sex couples see and experience their relationships. Nonmonogamous relationships have decreased in frequency among LGB individuals, who usually seek to establish stable, monogamous and long-term bonds with their partners (Gotta et al., 2011). Nevertheless, the literature suggests that monogamous relationships are not always associated with increased sexual satisfaction. 
The breaking of a sexual agreement (e.g. nonemotional involvement, casual sex only) and discrepancies in the experiences of each partner (e.g. one partner may have a higher number of extramarital partners than the other) may affect both marital and sexual satisfaction (Mitchell, Harvey, Champeau, Moskowitz, \& Seal, 2012).

According to the articles reviewed, the strongest contributors to marital satisfaction were disclosure of sexual orientation, respect to sexual agreements between partners, communication, cohesion, adequate sexual functioning and the presence of a social support network (e.g. Knoble \& Linville, 2012). High levels of marital satisfaction may, in turn, have a positive effect on the physical and psychological wellbeing of same-sex couples.

Although scarce, studies of sexual satisfaction in lesbian couples found that several predictive factors of sexual satisfaction in heterosexual women also applied to lesbian and bisexual individuals, such as: marital satisfaction, social support (including the legalization of same-sex marriage), sexual pleasure and functioning, and absence of depressive symptoms (e.g. Henderson et al., 2009). On the other hand, internalized homophobia and poor socioeconomic conditions were found to be negative predictors of sexual satisfaction in lesbian and bisexual women (Henderson et al., 2009).

Studies of domestic relationships revealed that lesbian partners report a more egalitarian division of financial responsibilities, as well as greater equality of communication and support, than heterosexual couples. Gay males, on the other hand, report lower equality of communication, support, and participation in decision-making than heterosexual men (Gotta et al., 2011).

The present findings suggested that the presence of a support network (in social, legal or family contexts) is an important predictor of marital satisfaction and is directly related to the well-being of the couple, decreasing the negative impact of stressors such as discrimination (e.g. Lomando et al., 2011). The role of the family of origin in social support networks was highlighted, as was the presence of social support in the face of illnesses, such as breast cancer, or mourning, such as the loss of a partner for non-HIV-related causes (e.g. Hornjatkevyc \& Alderson, 2011). Social support may therefore be an important protective factor against adversity, in addition to diminishing the negative impact of discrimination on same-sex couples.

The studies analyzed also discussed homophobia and its impact on the lives of samesex couples, as well as the strategies used by these individuals to overcome the effects of discrimination (Frost, 2011). Homophobia may be external, as in the case of open discrimination, as well as internal in the case of sexual minorities (Meyer, 2003). Internalized homophobia (the extent to which sexual minorities internalize negative attitudes towards homosexuality) appears to have a negative association with mental health in homosexual men and women (Frost \& Meyer, 2009). However, some gay and lesbian couples are able to reframe stigmarelated stress experiences as opportunities to (re)define their notions of commitment and relational legitimacy, as well as bring them closer to their partners and strengthen relational bonds (Frost, 2011). The present findings suggest that coping with both internal and external stigma is crucial for the psychological well-being and social adjustment of same-sex couples. Additional studies must be performed on the effects of internalized homophobia, especially due to its association with mental health in LGB populations (Frost \& Meyer, 2009).

\section{Final Considerations}

The aim of this study was to provide a picture of the national and international literature on LGB-parent families. The past five years (2009-2013) have seen a significant increase in the amount and comprehensiveness of research on the topic. The majority of studies in the area are international, empirical, cross-sectional, and quantitative, collecting their data with the use of interviews (qualitative studies) or standardized 
Table 2

Thematic Subcategories and Associated References in Studies Regarding Parenting and Marriage in LGB-Headed Families

\begin{tabular}{ll}
\hline \multicolumn{1}{c}{ Subcategories in LGB Parenting } & References \\
\hline $\begin{array}{l}\text { 1. Expectations, perceptions and transition } \\
\text { to parenthood ( } n=13)\end{array}$ & $\begin{array}{l}\text { Goldberg \& Smith, 2009, 2011; Naziri \& Feld- } \\
\text { Elzon, 2012; Riskind \& Patterson, 2010 }\end{array}$ \\
$\begin{array}{l}\text { 2. Routes to parenthood (assisted reproduction, } \\
\text { adoption and coparenting; } n=23)\end{array}$ & $\begin{array}{l}\text { Amazonas et al., 2013; Bos \& Gartrell, 2010b; } \\
\text { Freeman et al., 2009; Goldberg \& Allen, 2013; } \\
\text { Greenfeld \& Seli, 2011; Moás \& Correa, 2010 }\end{array}$ \\
$\begin{array}{l}\text { 3. Parent/child dynamics and functioning } \\
\text { (child psychosocial adjustment, parental roles, } \\
\text { sexual orientation of parents and children; } n=22)\end{array}$ & $\begin{array}{l}\text { Bos \& Gartrell, 2010a; Cohen \& Kuvalanka, 2011; } \\
\text { Farr et al., 2010; Gartrell et al., 2011; Martinez \& }\end{array}$ \\
$\begin{array}{l}\text { Barbieri, 2011; Schumm, 2010 } \\
\text { 4. Discrimination experiences (the impact } \\
\text { of homophobia on the life of LGB-parent families, } \\
\text { attitudes and beliefs regarding LGB parenting; } n=25)\end{array}$ & $\begin{array}{l}\text { Bos \& Gartrell, 2010b; Chapman et al., 2012; } \\
\text { Ferreira et al., 2012; Gato \& Fontaine, 2013; } \\
\text { Rodriguez \& Paiva, 2009 }\end{array}$ \\
$\begin{array}{l}\text { 5. Theoretical and methodological discussions } \\
\text { of parenthood (general theoretical discussions } \\
\text { of same-sex parenting; research methods } \\
\text { and instrument validation; } n=9 \text { ) }\end{array}$ & $\begin{array}{l}\text { Frias-Navarro \& Monterde-i-Bort, 2012; } \\
\text { Vilhena et al., 2011 }\end{array}$ \\
\hline
\end{tabular}

\section{Subcategories in LGB Marital Relationships}

1. Legalization of same-sex marriage and impact on the physical and mental health of couples $(n=17)$

2. Relationship dynamics in same-sex couples (marital satisfaction, sexual satisfaction, housework; $n=19$ )

3. Social support networks of same-sex couples $(n=10)$

4. Homophobia and its impact on the lives of couples $(n=9)$

\section{References}

Hatzenbuehler et al., 2012; Riggle et al., 2010; Wight et al., 2013

Gotta et al., 2011; Henderson et al., 2009; Knoble \& Linville, 2012; Mitchell et al., 2012

Hornjatkevyc \& Alderson, 2011;

Lomando et al., 2011

Frost, 2011; Frost \& Meyer, 2009 scales and questionnaires (qualitative studies). In Brazil, although the number of studies of LGBparent families is growing, most investigations are theoretical rather than empirical. The few existing empirical studies use qualitative methodologies and involve samples with low representativeness.

Most of the studies retrieved focus on lesbian mothers, although a growing number of studies have also evaluated gay parents and the offspring of sexual minorities. Bisexual and transgender couples, as well as their offspring (especially adult offspring), are even more scarcely studied. Most of the studies identified focused on parenthood rather than marital relationships. However, there has been an increase in the number of studies of planned LGBT families, and arrangements including assisted reproduction, and adoption.

The recent scientific literature on LGB parenting suggests that the psychosocial adjustment and psychological well-being of children and adolescents raised by sexual minorities are not influenced by their parents' sexual orientation. The quality of parent-child relationship dynamics appears to be the main predictor of parental competence. Nevertheless, homophobia (both internal and external) 
may be an important indicator of mental and physical well-being in same-sex couples, and of psychological well-being in their offspring (Bos \& Gartrell, 2010a; Goldberg \& Smith, 2009).

In the wake of recent legal changes to the status of same-sex marriage, several scientific studies have discussed the positive effects of marriage legalization on the lives of same-sex couples, and found it to be directly associated with physical and psychological well-being. Additionally, the literature shows that same-sex couples seek monogamous and lasting relationships, and experience similar issues to those reported by heterosexual couples (Frost, 2011; Gotta et al., 2011; Henderson et al., 2009). Homophobia appears to have a negative influence on the lives of same-sex couples through its impact on the mental health of the LGB population, resulting in lower levels of psychological wellbeing and social adjustment.

Despite notable advances in the size and representativeness of participant samples, and the increasing discussion of developmental processes in LGB-parent families - especially through longitudinal studies - several methodological issues were identified in the literature reviewed. Most studies involve samples with low representativeness, recruiting mostly urbandwelling Caucasian gay and lesbian adults, with a high socioeconomic status. Therefore, these studies cannot be generalized to bisexual and trans (transgender, transsexual and transvestite) populations, the elderly, black sexual minorities, low-income individuals, and residents of rural areas, who may have a dual minority status. Additionally, most of the studies reviewed have a cross-sectional design, and cannot determine causal relationships between the factors investigated.

Several topics have received little to no attention in the recent literature, such as: mourning (for partners or even children); divorce and remarriage; domestic violence in lesbian couples (Hardesty, Oswald, Khaw, \& Fonseca, 2009); adult offspring; successful assisted reproduction; family functioning when either one or both parents have HIV / AIDS or a chronic disease; impact of marriage legalization on the offspring of same-sex couples; parentchild sexual communication; and studies of older same-sex couples. Lastly, we suggest that studies take a more integrated look at each family, considering the role of each member of the family unit.

One of the main limitations of this review is the selection of keywords which emphasized gay- and lesbian-headed families, and did not include transgender, transvestite and transsexual populations. This may be why so few studies of these populations were identified. On the other hand, the keywords did include general references to homosexuality. As such, it is possible that this is not used as a keyword by studies involving trans populations.

Given the exploratory nature of the present study and the growing number of scientific publications on families formed by lesbian, gay and bisexual individuals, the main contribution of this review was to outline the current research on the topic and provide a comprehensive summary of major findings, as well as a critical evaluation of this complex and multifaceted scenario, in addition to suggesting avenues for future research.

\section{References}

*Amazonas, M. C. L. D. A., Veríssimo, H. V., \& Lourenço, G. O. (2013). A adoção de crianças por gays. Psicologia \& Sociedade, 25(3), 631641. doi:10.1590/S0102-71822013000300017

Azevedo, R. S. (2010). Sobrecarga do cuidador informal da pessoa idosa frágil: Uma revisão sistemática (Unpublished master's thesis, Universidade Federal de Minas Gerais, Belo Horizonte, MG, Brazil).

Bardin, L. (1979). Análise de conteúdo (L. Reto \& A. Pinheiro, Trans.). São Paulo, SP: Edições 70. (Original work published 1977)

Biblarz, T. J., \& Stacey, J. (2010). How does the gender of parents matter? Journal of Marriage and Family, 72, 3-22. doi:10.1111/j.17413737.2009.00678.x

*Bos, H. M. W., \& Gartrell, N. K. (2010a). Adolescents of the US National Longitudinal Lesbian Family Study: The impact of having a known or an unknown donor on the stability of psycho- 
logical adjustment. Human Reproduction, 26(3), 630-637. doi:10.1093/humrep/deq359

*Bos, H. M. W., \& Gartrell, N. K. (2010b). Adolescents of the USA National Longitudinal Lesbian Family Study: Can family characteristics counteract the negative effects of stigmatization? Family Process, 49(4), 559-572. doi:10.1111/j.1545-5300.2010.01340.x

*Cecílio, M. S., Scorsolini-Comin, F., \& Santos, M. A. D. (2013). Scientific production on adoption by gay couples in Brazilian context. Estudos de Psicologia (Natal), 18(3), 507-516. doi:10.1590/ S1413-294X2013000300011

*Chapman, R., Wardrop, J., Freeman, P., Zappia, T., Watkins, R., \& Shields, L. (2012). A descriptive study of the experiences of lesbian, gay and transgender parents accessing health services for their children. Journal of Clinical Nursing, 21(7 - 8), 1128-1135. doi:10.1111/ j.1365-2702.2011.03939.x

*Cohen, R., \& Kuvalanka, K. A. (2011). Sexual socialization in lesbian-parent families: An exploratory analysis. American Journal of Orthopsychiatry, 81(2), 293. doi:10.1111/ j.1939-0025.2011.01098.x

Costa, A. B., \& Zolowski, A. P. C. (2014). Como escrever um artigo de revisão sistemática. In S. H. Koller, M. C. P. P. Couto, \& J. Von Hohendorff (Eds.), Manual de Produção Científica (pp. 5570). Porto Alegre, RS: Penso.

*Costa, P. A., Caldeira, S., Fernandes, I., Rita, C., Pereira, H., \& Leal, I. (2013). Atitudes da população portuguesa em relação à Homoparentalidade. Psicologia: Reflexão e Crítica, 26(4), 790798. doi:10.1590/S0102-79722013000400020

*Farias, M. O. (2010). Mitos atribuídos às pessoas homossexuais e o preconceito em relação à conjugalidade homossexual e a homoparentalidade. Revista de Psicologia da UNESP, 9(1), 104-115. Retrieved from http://186.217.160.122/ revpsico/index.php/revista/article/download/169/211

*Farr, R. H., Forssell, S., \& Patterson, C. J. (2010). Parenting and child development in adoptive families: Does parental sexual orientation matter? Applied Developmental Science, 10, 164 178. doi:10.1080/10888691.2010.500958

*Farr, R. H., \& Patterson, C. J. (2013). Coparenting among lesbian, gay, and heterosexual couples: Associations with adopted children's out- comes. Child Development, 84(4), 1226-1240. doi:10.1111/cdev.12046

*Ferreira, S. P. A., Cadete, V. G., \& da Silva, D. B. (2012). Os sentidos e os significados produzidos pela escola em relação à família homoparental: Um estudo de caso. Interação em Psicologia, 16(1). doi:10.5380/psi.v16i1.13947

*Freeman, T., Jadva, V., Kramer, W., \& Golombok, S. (2009). Gamete donation: Parents' experiences of searching for their child's donor siblings and donor. Human Reproduction, 24(3), 505-516. doi:10.1093/humrep/den469

*Frias-Navarro, D., \& Monterde-i-Bort, H. (2012). A scale on beliefs about children's adjustment in same-sex families: Reliability and validity. Journal of Homosexuality, 59(9), 1273-1288. doi:10.1080/00918369.2012.720505

*Frisch, M., \& Brønnum-Hansen, H. (2009). Mortality among men and women in same-sex marriage: A National Cohort Study of 8333 Danes. American Journal of Public Health, 99(1), 133. doi:10.2105/AJPH.2008.133801

*Frost, D. M. (2011). Stigma and intimacy in samesex relationships: A narrative approach. Journal of Family Psychology, 25(1), 1. doi:10.1037/ $\mathrm{a} 0022374$

*Frost, D. M., \& Meyer, I. H. (2009). Internalized homophobia and relationship quality among lesbians, gay men, and bisexuals. Journal of Counseling Psychology, 56, 97-109.

*Gartrell, N. K., \&, Bos, H. M. W. (2010). The US National Longitudinal Lesbian Family Study: Psychological adjustment of 17-year-old adolescents. Pediatrics, 126, 1-9. doi:10.1542/ peds.2009-3153

*Gartrell, N. K., Bos, H. M., \& Goldberg, N. G. (2011). Adolescents of the US National Longitudinal Lesbian Family Study: Sexual orientation, sexual behavior, and sexual risk exposure. Archives of Sexual Behavior, 40(6), 1199-1209. doi:10.1007/s10508-010-9692-2

*Gartrell, N. K., Bos, H. M. W., Peyser, H., Deck, A., \& Rodas, C. (2012). Adolescents with lesbian mothers describe their own lives. Journal of Homosexuality, 59, 1211-1229. doi:10.1080/ 00918369.2012.720499

*Gato, J., \& Fontaine, A. M. (2013). Anticipation of the sexual and gender development of children adopted by same-sex couples. International 
Journal of Psychology, 48(3), 244-253. doi:10. 1080/00207594.2011.645484

*Goldberg, A. E. (2009). Lesbian and heterosexual preadoptive couples' openness to transracial adoption. American Journal of Orthopsychiatry, 79(1), 103. doi:10.1037/a0015354

*Goldberg, A. E., \& Allen, K. R. (2013). Donor, dad, or...? Young adults with lesbian parents' experiences with known donors. Family Process, 52(2), 338-350. doi:10.1111/famp.12029

Goldberg, A. E., \& Gartrell, N. K. (2014). LGBparent families: The current state of the research and directions for the future. Advances in Child Development and Behavior, 46, 57-88. doi:10.1016/B978-0-12-800285-8.00003-0

*Goldberg, A. E., \& Smith, J. Z. (2009). Perceived parenting skill across the transition to adoptive parenthood among lesbian, gay, and heterosexual couples. Journal of Family Psychology, 23(6), 861. doi:10.1037/a0017009

*Goldberg, A. E., \& Smith, J. Z. (2011). Stigma, social context, and mental health: Lesbian and gay couples across the transition to adoptive parenthood. Journal of Counseling Psychology, 58(1), 139. doi:10.1037/a0021684

*Goldberg, A. E., \& Smith, J. Z. (2013). Predictors of psychological adjustment among early placed adopted children with lesbian, gay, and heterosexual parents. Journal of Family Psychology, 27, 431-442. doi:10.1037/a0032911

*Gotta, G., Green, R. J., Rothblum, E., Solomon, S., Balsam, K., \& Schwartz, P. (2011). Heterosexual, lesbian, and gay male relationships: A comparison of couples in 1975 and 2000. Family Process, 50(3), 353-376. doi:10.1111/j.15455300.2011.01365.x

*Greenfeld, D. A., \& Seli, E. (2011). Gay men choosing parenthood through assisted reproduction: Medical and psychosocial considerations. Fertility and Sterility, 95(1), 225-229. doi:10.1016/j. fertnstert.2010.05.053

*Grover, S. A., Shmorgun, Z., Moskovtsev, S. I., Baratz, A., \& Librach, C. L. (2013). Assisted reproduction in a cohort of same-sex male couples and single men. Reproductive Biomedicine Online, 27(2), 217-221. doi:10.1016/j. rbmo.2013.05.003

*Hardesty, J. L., Oswald, R. F., Khaw, L., \& Fonseca, C. (2009). Lesbian/bisexual mothers and intimate partner violence: Help seeking in the context of social and legal vulnerability. Violence against Women, 17(1), 28-46. doi:10.1177/1077801209347636

*Hatzenbuehler, M. L., O’Cleirigh, C., Grasso, C., Mayer, K., Safren, S., \& Bradford, J. (2012). Effect of same-sex marriage laws on health care use and expenditures in sexual minority men: A quasi-natural experiment. American Journal of Public Health, 102(2), 285-291. doi:10.2105/ AJPH.2011.300382

*Henderson, A. W., Lehavot, K., \& Simoni, J. M. (2009). Ecological models of sexual satisfaction among lesbian/bisexual and heterosexual women. Archives of Sexual Behavior, 38(1), 5065. doi:10.1007/s10508-008-9384-3

Herek, G. M. (2000). Sexual prejudice and gender: Do homosexuals attitudes toward lesbian and gay men differ? Journal of Social Issues, 56, 251-266.

*Hornjatkevyc, N. L., \& Alderson, K. G. (2011). With and with out: The bereavement experiences of gay men who have lost a partner to non-AIDSrelated causes. Death Studies, 35(9), 801-823. doi:10.1080/07481187.2011.553502

Johnson, S. M. (2012). Lesbian mothers and their children: The third wave. Journal of Lesbian Studies, 16(1), 45-53. doi:10.1080/10894160.2 011.557642

*Knauer, N. J. (2012). Legal consciousness and LGBT research: The role of the law in the everyday lives of LGBT individuals. Journal of Homosexuality, 59(5), 748-756. doi:10.1080/00 918369.2012.673947

*Knoble, N. B., \& Linville, D. (2012). Outness and relationship satisfaction in same-gender couples. Journal of Marital and Family Therapy, 38(2), 330-339. doi:10.1111/j.17520606.2010.00206.x

*Lomando, E., Wagner, A., \& Gonçalves, J. (2011). Coesão, adaptabilidade e rede social no relacionamento conjugal homossexual. Psicologia: Teoria e Prática, 13(3), 96-109. Retrieved from http://pepsic.bvsalud.org/scielo.php?script $=$ sci arttext\&pid=S1516-36872011000300008

*Martinez, A. L. M., \& Barbieri, V. (2011). A experiência da maternidade em uma família homoafetiva feminina. Estudos de Psicologia (Campinas), 28(2), 175-185. doi:10.1590/ S0103-166X2011000200005 
Meyer, I. H. (2003). Prejudice, social stress, and mental health in lesbian, gay, and bisexual populations: Conceptual issues and research evidence. Psychological Bulletin, 129, 674-697. doi:10.1037/0033-2909.129.5.674

*Mitchell, J. W., Harvey, S. M., Champeau, D., Moskowitz, D. A., \& Seal, D. W. (2012). Relationship factors associated with gay male couples' concordance on aspects of their sexual agreements: Establishment, type, and adherence. AIDS and Behavior, 16(6), 15601569. doi:10.1007/s10461-011-0064-2

*Moás, L. D. C., \& Correa, M. C. D. V. (2010). Filiação e tecnologias de reprodução assistida: Entre medicina e direito. Physis, 20(2), 591-607. doi:10.1590/S0103-73312010000200014

*Naziri, D., \& Feld - Elzon, E. (2012). Becoming a mother by "aid" within a lesbian couple: The issue of the third. The Psychoanalytic Quarterly, 81(3), 683-711. doi:10.1002/j.2167-4086.2012.tb00514.x

*Power, J. J., Perlesz, A., Schofield, M. J., Pitts, M. K., Brown, R., McNair, R., ...Bickerdike, A. (2010). Understanding resilience in same-sex parented families: The work, love, play study. $B M C$ Public Health, 10(1), 115. doi:10.1186/14712458-10-115

*Riggle, E. D., Rostosky, S. S., \& Horne, S. G. (2010). Psychological distress, well-being, and legal recognition in same-sex couple relationships. Journal of Family Psychology, 24(1), 82. doi:10.1037/a0017942

*Riskind, R. G., \& Patterson, C. J. (2010). Parenting intentions and desires among childless lesbian, gay, and heterosexual individuals. Journal of Family Psychology, 24(1), 78. doi:10.1037/ a0017941

*Riskind, R. G., Patterson, C. J., \& Nosek, B. A. (2013). Childless lesbian and gay adults' selfefficacy about achieving parenthood. Couple and Family Psychology: Research and Practice, 2(3), 222. doi:10.2139/ssrn.2095376

*Rodriguez, B. C., \& Gomes, I. C. (2012). Novas formas de parentalidade: Do modelo tradicional à homoparentalidade. Boletim de Psicologia, 62(136), 29-36. Retrieved from http:// pepsic.bvsalud.org/scielo.php?pid=S000659432012000100004\&script=sci_arttext

*Rodriguez, B. C., \& Paiva, M. L. D. S. C. (2009). Um estudo sobre o exercício da parentali- dade em contexto homoparental. Vínculo, 6(1), 13-25. Retrieved from http://pepsic. bvsalud.org/scielo.php?script=sci arttext\&pid $=\mathrm{S} 1806-24902009000100003$

*Ryan, M. (2013). The gender of pregnancy: Masculine lesbians talk about reproduction. Journal of Lesbian Studies, 17(2), 119-133. doi:10.1080/10 894160.2012 .653766

Santos, Y. G. S., Scorsolini-Comin, F., \& Santos, M. A. (2013). Homoparentalidade masculina: Revisando a produção científica. Psicologia: Reflexão e Crítica, 26(3), 572-582. doi:10.1590/ S0102-79722013000300017

*Schumm, W. R. (2010). Children of homosexuals more apt to be homosexuals? A reply to Morrison and to Cameron based on an examination of multiple sources of data. Journal of Biosocial Science, 42(06), 721-742. doi:10.10017/ S0021932010000325

*Smith, M. K., Willmott, L., Trowse, P., \& White, B. P. (2013). Back to the future: Prohibiting surrogacy for singles, same-sex and shorter-term heterosexual couples in Queensland. Journal of Law and Medicine, 20(3), 638-654. Retrieved from http://www.ncbi.nlm.nih.gov/ pubmed/23600195

*Tarnovski, F. L. (2011). Les coparentalités entre gays et lesbiennes en France: le point de vue des pères. Vibrant: Virtual Brazilian Anthropology, 8(2), 140-163. doi:10.1590/S180943412011000200007

*Tarnovski, F. L. (2013). Parentalidade e gênero em famílias homoparentais francesas. Cadernos Pagu, 40, 67-93. doi:10.1590/S010483332013000100002

Tasker, F. L., \& Golombok, S. (1997). Growing up in a lesbian family: Effects on child development. London: Guilford Press.

*Tornello, S. L., Farr, R. H., \& Patterson, C. J. (2011). Predictors of parenting stress among gay adoptive fathers in the United States. Journal of Family Psychology, 25(4), 591. doi:10.1037/ a0024480

Vecho, O., \& Schneider, B. (2005). Homoparentalité et développement de l'enfant: bilan de trente ans de publications. La Psychiatrie de l'Enfant, 481, 271-328. doi:10.3917/psye.481.0271

*Vilhena, J. D., Souza, A. C. B. D., Uziel, A. P., Zamora, M. H., \& Novaes, J. V. (2011). Que família?: Provocações a partir da homoparentali- 
dade. Revista Mal Estar e Subjetividade, 11(4), 1639-1658. Retrieved from http://pepsic. bvsalud.org/scielo.php?script=sci_arttext\&pid $=$ S1518-61482011000400014

*Wight, R. G., LeBlanc, A. J., \& Lee Badgett, M. V. (2013). Same-sex legal marriage and psychological well-being: Findings from the California Health Interview Survey. American Journal of Public Health, 103(2), 339-346. doi:10.2105/ AJPH.2012.301113

*Yager, C., Brennan, D., Steele, L. S., Epstein, R., \& Ross, L. E. (2010). Challenges and mental health experiences of lesbian and bisexual women who are trying to conceive. Health \& Social Work, 35(3), 191-200. Retrieved from http:// www.ncbi.nlm.nih.gov/pubmed/20853646
*Zanghellini, A. (2010). Queer kinship practices in non-western contexts: French Polynesia's gender-variant parents and the law of $\mathrm{La}$ République. Journal of Law and Society, 37(4), 651-677. Retrieved from http://www.ncbi.nlm. nih.gov/pubmed/21125769

Recebido: $29 / 05 / 2015$

$1^{a}$ revisão: $31 / 08 / 2015$

Aceite final: 10/09/2015 